\title{
Analysis of Business Plan Preparation Applications as an Effort to Achieve Business Success for Entrepreneurs of Kediri
}

\author{
Sri Wahyuni Mega Hastuti ${ }^{1}$, Bayu Surindra ${ }^{2}$ \\ ${ }^{1}$ Postgraduate, Kadiri Islamic University of Kediri, Indonesia \\ ${ }^{2}$ Department of Economics Education, Nusantara PGRI University of Kediri, Indonesia
}

Corresponding Author: Sri Wahyuni Mega Hastuti

\section{ABSTRACT}

The research, entitled Analysis of Business Plan Preparation Applications as an Effort to Achieve Business Success for Kediri City Entrepreneurs is a descriptive research, this study examines efforts to achieve business success through the preparation of a business plan. The application for the preparation of a business plan prepared by entrepreneurs Kediri city includes aspects of customer segments, customer relations, bargaining value, promotions, main resources, main activities, relationships with partners and sources of income for entrepreneurs. The population that became the respondents in this study was obtained from the results of the competition for the leading entrepreneur in Kediri city were 100 respondents. The purpose of this study was to determine: (1) the types of businesses found in Kediri city in terms of the results of the preparation of business plans for business practitioner in Kediri city, (2) the market segment that became the customer service orientation of the business practitioners in Kediri city, (3) the types of business promotions carried out by Kediri City entrepreneurs, (4) The way Kediri business practitioner in fostering relationships with customers, (5) Types of advantages/bargaining power provided by Kediri City entrepreneurs to consumers/customers, (6) Sources needed by business practitioners in Kediri city, (7) business partners for business practitioners in the city of Kediri, (8) sources of income from whatever is obtained from business practitioners Kediri city. Data analysis technique is qualitative descriptive analysis. The results of the study indicate that: (1) The types of businesses in the City of Kediri
\end{abstract}

are in the fields of food, beverages, accessories, souvenirs, educational institution services, beauty services, batik, weaving, tailoring, Muslim clothing, t-shirt producing; (2) The market segments as costumer service orientation of the leading business practitioners in Kediri City are mostly adult and adolescent consumers; (3) the most business promotions are exhibitions, online media, social media, banners, business cards, brochures and direct selling; (4) Planning to build relationships with customers through intensive communication with customers, after-sales service and making membership cards (members); (5) The most advantage/bargaining power is to provide excellent service, affordable prices, quality products; (6) the most resource requirements planned are capital, labour, raw materials and equipment; (7) Most Business Partners are Government Agencies and supported by other partners; and (8) The source of income is from the sale of products and from several other sources of income as addition.

Keywords: Business plan, customer segment, promotion, bargaining value, business partner

\section{INTRODUCTION}

One causes of the slow development of micro and small businesses is that businessmen are not yet accustomed to making a good business plan. Business plan is a form of business arranged before the business is run and covering various aspects that affect business development. "The business plan is written document prepared by the entrepreneur that describes all the 
relevant external and internal elements involved in starting a new venture. It is often an integration on functional plans such as marketing, finance, manufacturing and human resources" (Hisrich \& Peter, 2008). A business plan is a business plan that will be carried out in the future by looking at the most important practitioners in overcoming problems and seeing opportunities (Supriyanto, 2009). A business plan is an important thing, especially to find out the weaknesses, strengths, advantages and disadvantages of a business that will be started (Andayani et al., 2018). A business plan is a document made by a businessman and the document explains the elements contained in the business, both internal and external elements before starting a business (Aries Suprapto \& Rusdi, 2018).

Business plan is all activities carried out in the future in achieving a predetermined goal (Muhammad Hasyim, 2014). So a business plan or is a file that will be prepared by entrepreneurs in describing all aspects both internal and external to start a business. The business plan usually includes planning for marketing, capital, promotion and the resources used, as well as explaining the steps that can be used to see business opportunities so that they can be realized into real businesses. A business plan is a plan that is prepared in the form of a document that becomes a reference regarding the beliefs and abilities of the business to trade goods or services in the hope of obtaining profits so that they are able to satisfy and attract investors (Bygrave, 1994) in (Alma, 2007). The purpose of a business plan is to implement the business remains on the right track as previously planned (Farida et al., 2019). Several things are contained in the business plan involves marketing problems, business capital problems, manufacturing problems, and HR problems in the business (Ali \& Soegoto, 2016).

The business plan contains several important formats, including: 1) business executive summary; 2) business introduction; 3) business objectives; 4) business background; 5) the background of the business owner; 6) business organizational structure; 7) business marketing plan; and 8) business financial plan (Sukirno, 2004) in (Kristianto, 2012). Furthermore, there are several things that are deemed necessary to be taken into account, especially in making business plans, including: 1) the existence of a business plan template; 2) carry out research in search of initial information; 3) the business plan is packaged as attractively as possible; 4) conduct consultations with business experts; 5) formulate strategies in terms of marketing or promotion; 6) analyze the projected cash flow of the business; 7) modify the business plan according to the conditions if necessary; 8) not too optimistic about high and low sales; and 9) reduce the emphasis on long-term business projections but concentrate on short-term projections first (Mudjahidin, 2005). With a mature business plan and an important format in business planning, it will be easier for business practitioners to introduce their products so as to facilitate the business management process. If an entrepreneur is not able to make a business plan properly, it is like someone who walks without direction and guidance. On the other hand, if the entrepreneur can make a careful business plan, then half of the business has started well, the control has been carried out, the risk has been anticipated, and even the profit has been estimated, so that the business steps can run steadily because there is a reference to guide them.

The research problems are: (1) What types of businesses are there in Kediri resulted by the preparation of business plans by entrepreneurs of Kediri; (2) Which market segments are customer service orientations of Kediri's businessmen?; (3) How does the entrepreneur promote the business?; (4) How are the Kediri business practitioners in fostering relationships with customers?; (5) What types of advantages/bargaining power are provided by the business practitioner of Kediri to 
customers/consumers?; (6) What resources are needed by the entrepreneurs of Kediri?; (7) Who are the business partners of Kediri city entrepreneurs?; and (8) Where the source of income is obtained by the business practitioners of the City of Kediri.

The objectives of the study are to determine: (1) the types of businesses in Kediri in resulted by preparation of business plans for business practitioner in the City of Kediri; (2) The market segment which became customer service orientation for the business practitioner of the City of Kediri; (3) Types of business promotion carried out by entrepreneurs of the City of Kediri; (4) The method of Kediri business practitioners in fostering relationships with customers; (5) Types of advantages/bargaining power provided by the business practitioners of the City of Kediri to consumers/customers; (6) My sources needed by business practitioners in the City of Kediri; (7) business partners of Kediri city entrepreneurs; and (8) The source of income from whatever is obtained from business practitioners in the City of Kediri.

\section{MATERIALS \& METHODS}

Analysis of the Business Plan Preparation Application is a descriptive research because this research only has one variable, the analysis of the business plan prepared by entrepreneurs of the Kediri. The activity stages begin with the preparation of business plan materials, dissemination of materials to respondents, application of business plan preparation by business practitioners, data input, data processing, data validation. The results of the analysis in descriptive form are to answer the research problems carried out by extracting both primary and secondary data. Descriptive analysis is used to find data by exporting directly to respondents to collect the required data (Purnamasari et al., 2018). Primary data was obtained from the application of business plan preparation from leading business practitioners in Kediri. In addition to primary data, secondary data is also needed which is obtained from relevant research reports, it can also be obtained from various documentation available at the Department of Cooperatives for Micro Enterprises and labor of Kediri.

The basis for determining the population as respondents in this study is the result of the selection of leading business practitioners in Kediri. A total of 100 leading business practitioners in Kediri were given training in business plan preparation techniques. The results of the preparation of the business plan by the respondents were analyzed further in order to answer the problems in this research. The population criteria in this study are as follows: (1) MSMEs that carry out the process of processing materials into final products or there are production processes; (2) Kediri City's leading product; (3) Potential for domestic and export markets; (4) The production is continuous; and (5) Willing to prepare a business plan.

The analysis technique used in this Business Plan Application Research is descriptive analysis, which is analyzing the results of the business plan application compiled by 100 business practitioners in Kediri. The data analysis process were as follows: (1) Business plan application, (2) Data input, (3) Data tabulation, (4) Data editing, (5) Compilation of data tabulation results into easy-to-read tables, (6) Making diagrams to facilitate the discussion of research results, (7) Analysis of research results.

\section{RESULT}

Based on the results of the input data for the business plan application research compiled by 100 entrepreneurs in Kediri as respondents, it can be seen from the following tables:

Table 1. Recapitulation of Research Results on the Business Plan Application of Kediri City Entrepreneurs in terms of Customer Segments

\begin{tabular}{|l|l|l|}
\hline No & Customer Segments & Numbers \\
\hline 1 & All People & 39 \\
\hline 2 & Children & 5 \\
\hline 3 & Adults and Teens & 40 \\
\hline 4 & Segmentation for Men and Women & 16 \\
\hline
\end{tabular}
Source: processed data, 2021 
Sri Wahyuni Mega Hastuti et.al. Analysis of business plan preparation applications as an effort to achieve business success for entrepreneurs of Kediri.

Table 2. Recapitulation of Research Results of Business Plan Applications in terms of Bargaining Power

\begin{tabular}{|l|l|l|}
\hline No & Types of Bargain Value & Numbers \\
\hline 1 & Product quality & 19 \\
\hline 2 & Affordable prices & 25 \\
\hline 3 & Attractive Packing & 10 \\
\hline 4 & Service & 28 \\
\hline 5 & Attractive Design & 18 \\
\hline 6 & Go Green & 1 \\
\hline \multicolumn{2}{|c|}{ Source: processed data, 2021 } \\
\hline
\end{tabular}

Table 3. Recapitulation of Research Results on Business Plan Applications from the Aspect of Business Promotion

\begin{tabular}{|l|l|l|}
\hline No & Promotion Channel & Amount \\
\hline 1 & Exhibition & 27 \\
\hline 2 & Social Media/ Mass Media, Online & 27 \\
\hline 3 & Words of mouth & 8 \\
\hline 4 & Banner & 14 \\
\hline 5 & Catalog/ Brochure/ Business Card & 24 \\
\hline \multicolumn{2}{|c|}{ Source: processed data, 2021 } \\
\hline
\end{tabular}

Table 4. Recapitulation of Research Results of Business Plan Applications from the Aspect of Relationships with Customers

\begin{tabular}{|l|l|l|}
\hline No & Relationship with Customers & Numbers \\
\hline 1 & Good service & 35 \\
\hline 2 & Frequent Communication & 37 \\
\hline 3 & Giving Bonus/Gift & 13 \\
\hline 4 & Cooperation with other parties & 2 \\
\hline 5 & Member & 13 \\
\hline \multicolumn{2}{|c|}{ Source: processed data, 2021 } \\
\hline
\end{tabular}

\section{DISCUSSION}

The results of the discussion in this study can be explained in depth from the following processed data:
Table 5. Recapitulation of Research Results of Business Plan Applications From Main Resources Aspects

\begin{tabular}{|l|l|l|}
\hline No & Main Resources & Numbers \\
\hline 1 & Labors & 19 \\
\hline 2 & Capital & 76 \\
\hline 3 & Material & 4 \\
\hline 4 & Tools & 1 \\
\hline \multicolumn{2}{|c|}{ Source: processed data, 2021} \\
\hline
\end{tabular}

Table 6. Recapitulation of Research Results on Business Plan Applications in terms of Main Activities

\begin{tabular}{|l|l|l|}
\hline No & Main Activities & Numbers \\
\hline 1 & Production & 47 \\
\hline 2 & Marketing & 26 \\
\hline 3 & Others & 27 \\
\hline \multicolumn{2}{|c|}{ Source: processed data, 2021 } \\
\hline
\end{tabular}

Table 7. Recapitulation of Research Results on Business Plan Applications From the Main Partner Aspect

\begin{tabular}{|l|l|l|}
\hline No & Main Partners & Amount \\
\hline 1 & Agent/Distributor & 34 \\
\hline 2 & Related Offices/ Government Agencies & 53 \\
\hline 3 & Community & 7 \\
\hline 4 & Banking Source: processed data, 2021 & 6 \\
\hline \multicolumn{2}{|c|}{}
\end{tabular}

Table 8. Recapitulation of Research Results on Business Plan Applications in terms of Revenue Earnings

\begin{tabular}{|l|l|l|}
\hline No & Revenue Earning & Numbers \\
\hline 1 & Selling & 75 \\
\hline 2 & Instructor & 6 \\
\hline 3 & Others & 19 \\
\hline \multicolumn{2}{|c|}{ Source: processed data 2021} \\
\hline
\end{tabular}

Source: processed data, 2021

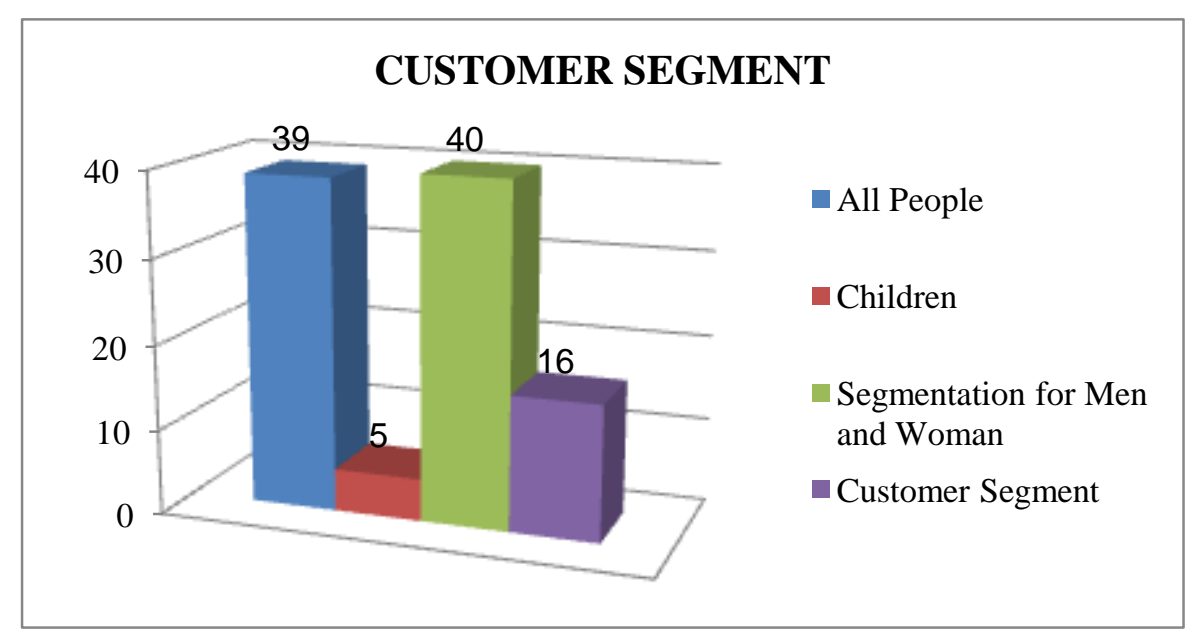

Figure 1. Customer Segment

The analysis shows that of the 100 respondents, who make business plans, it can be seen from the aspect of the customer segment targeted like the adult and youth segment by $40 \%$, followed by the segment of all groups by $35 \%$, the male segment by $16 \%$ and the lowest children segment is only $5 \%$. This means that Kediri entrepreneurs, are oriented to the adult and youth segments and all groups, this can be associated with the expected profit to be obtained. Entrepreneurs consider that the largest business profits are obtained from the adult and youth segments as well as all groups, as it is seen from the constructive nature of adult consumers. The children's segment is last in rank because the children's market is worried not to be a potential market. Almost all purchases are made by adults. 


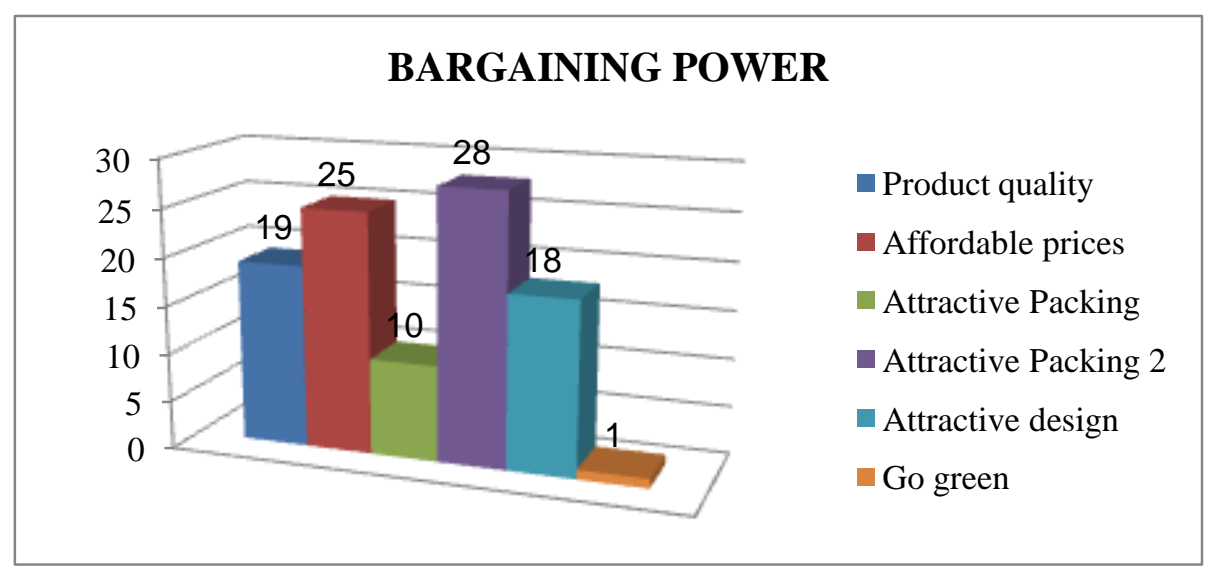

Figure 2. Bargaining Power

Seeing from the "Bargaining Power" aspect, it can be described that business practitioners plan to provide bargaining power or finer value from the business carried out, which is at most $28 \%$ in service, followed by affordable prices by $25 \%$, product quality by $19 \%$, then followed by Design and attractive packaging. The analysis the plan provides business excellence in services shows that the entrepreneurs of Kediri are getting smarter.
They are already customer oriented where customer conditions are always changing along with the progress of human civilization. Recently, it is increasingly popularized that a successful business is one that prioritizes customer satisfaction. Thus, it would be right when Kediri City entrepreneurs in preparing plans is to provide bargaining power in the form of the best service to customers.

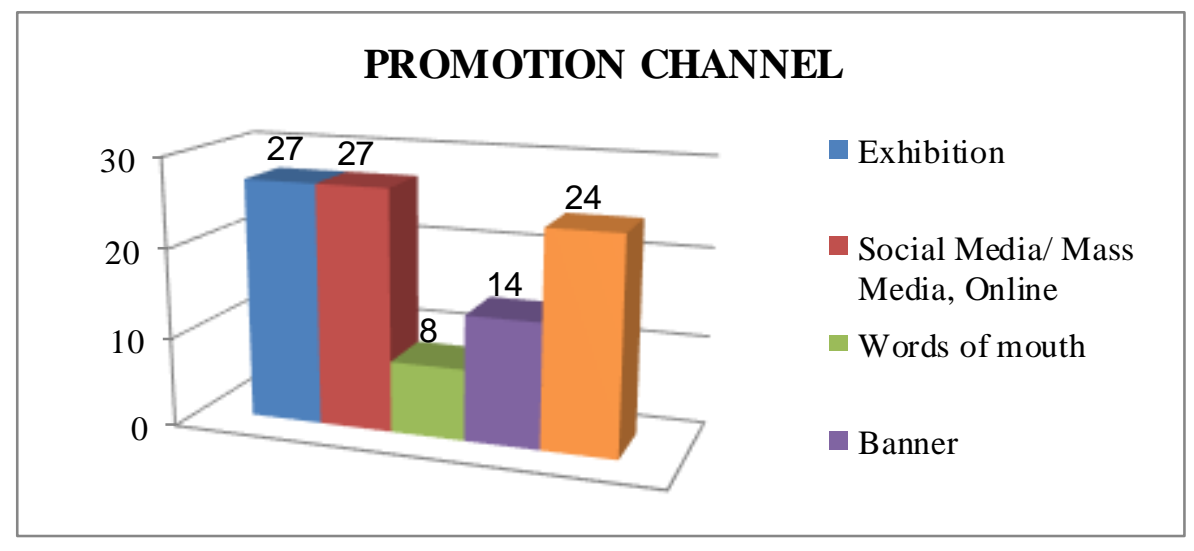

Figure 3. Promotion Channel

Aspects of how to introduce products to consumers or business promotions that mostly plan via exhibitions and online marketing and promotions through social media are $27 \%$. The next method of promotion is by making brochures, business cards by $25 \%$, and providing banner by $14 \%$ and word of mouth promotion ranks last. It can be analyzed that business practitioner have planned the most promotions by participating in exhibitions. This is understandable, due to the support of the government, various agencies that foster MSMEs, the most prominent program is the facilitation of marketing MSME products by participating in various exhibitions both national and abroad. Every entrepreneur is interested in exhibiting their products to the exhibition, so in the preparation of business plans, exhibition promotion ranks first. 


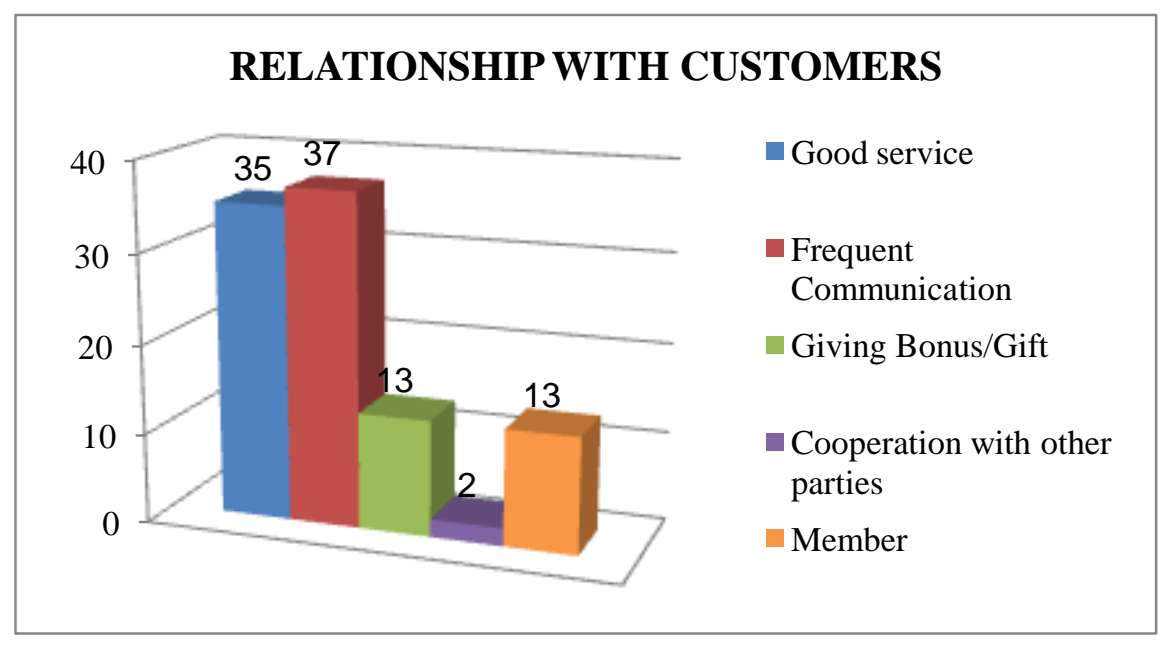

Figure 4. Relationship with Customers

Kediri City entrepreneurs plan to have relationship with post-purchase customers by frequently communicating with customers by $37 \%$, providing postpurchase service by $35 \%$ and making membership cards (members) by $13 \%$. It can be analyzed that maintaining relationships with consumers is absolutely necessary in business activities, so that customers who are already familiar with the products purchased, will come back again, become loyal customers. Repeat purchases mean entrepreneurs have been able to create loyal customers. The way to form loyal customers is to maintain relationships with consumers who have made purchases, by maintaining continuous communication.

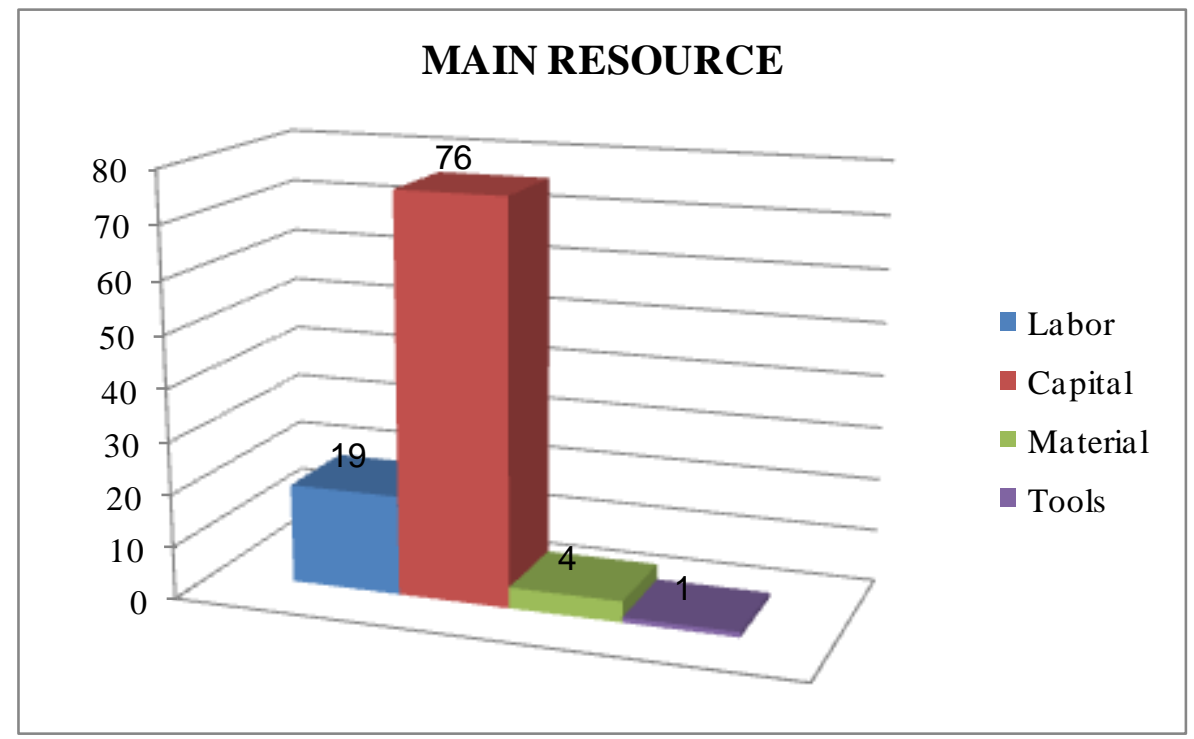

Figure 5. Main Resource

Figure 5 shows that $76 \%$, Kediri entrepreneurs plan the main business resource is capital followed by $19 \%$ of labour, raw materials and equipment. This can be explained that most entrepreneurs think that the main resource that must be owned in running a business is related to capital. Entrepreneurs still think that without capital the business will not run, so it is not a surprise that in the application for preparing a business plan, they use capital as the main resource in their business then followed by human resources, raw materials and equipment. 


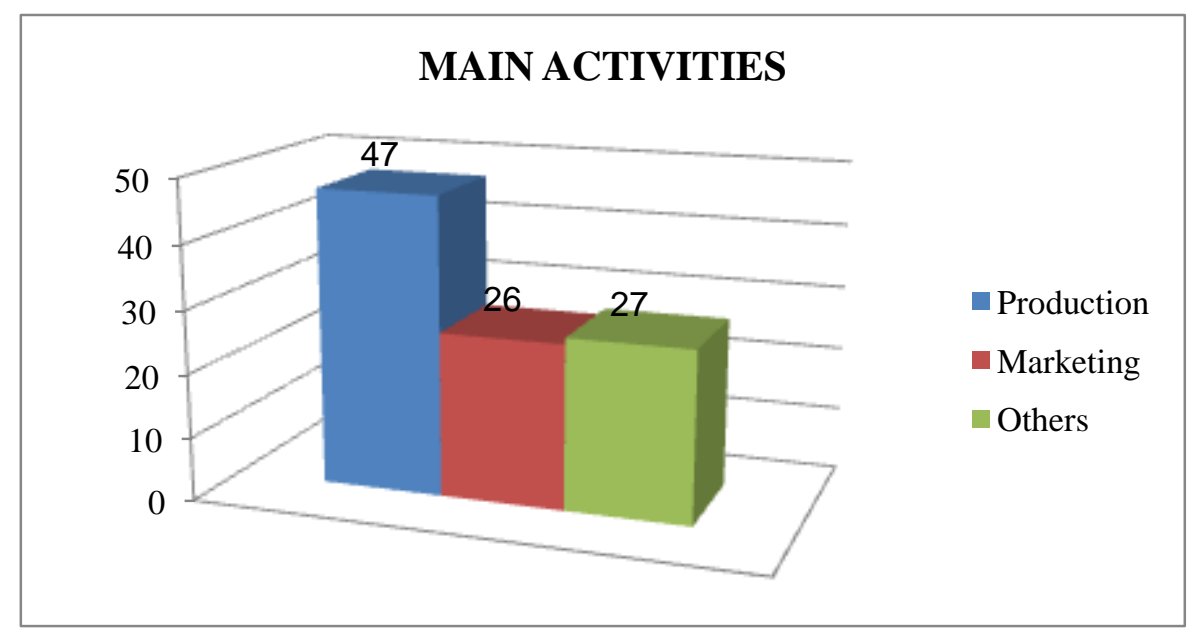

Figure 6. Main Activities

Seeing from the main activity in doing business, most entrepreneurs stated that the main activity was carrying out the production process by $47 \%$ and marketing by $26 \%$. The remaining percentage is filled with other activities such as: managing labours, recording business transactions, making purchases, conducting partnerships. It can be analyzed that the most priority of business plan is to carry out the production process, because entrepreneurs think that the production process is the activity that takes the most time, thought and energy and as the main activity so that there are products that can be sold and offered, then there are others activities such as selling, promoting, doing bookkeeping and other activities.

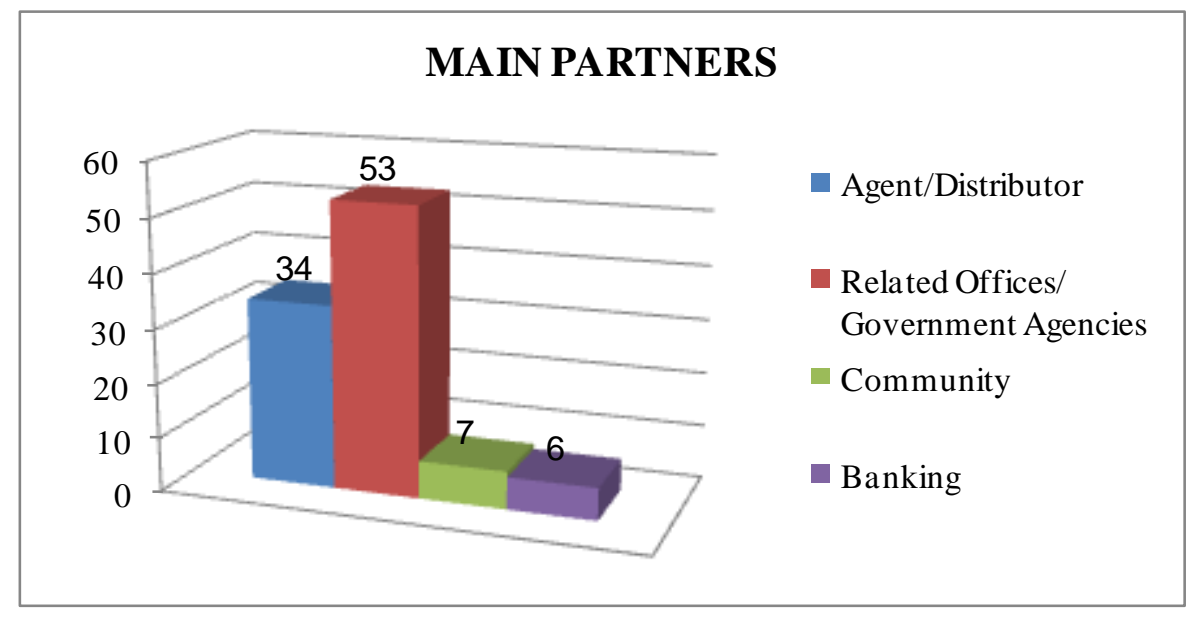

Figure 7. Main Partners

Most of the Kediri businesses practitioners plan to partner with Government Agencies by 53\%, the main partners in other businesses are distributors or agents by $34 \%$, other partners such as communities and banking. Entrepreneurs in Kediri, mostly determine that their main business partners are Government Agencies because entrepreneurs really hope to get business development facilitation from the government such as: training, exhibitions, business capital grants, equipment grants, and others. Meanwhile, Distributor's business partners are considered as things that should be done in business. Other partners are banking and communities such as: consumer communities, associations, social gathering associations, Quran recitations. 


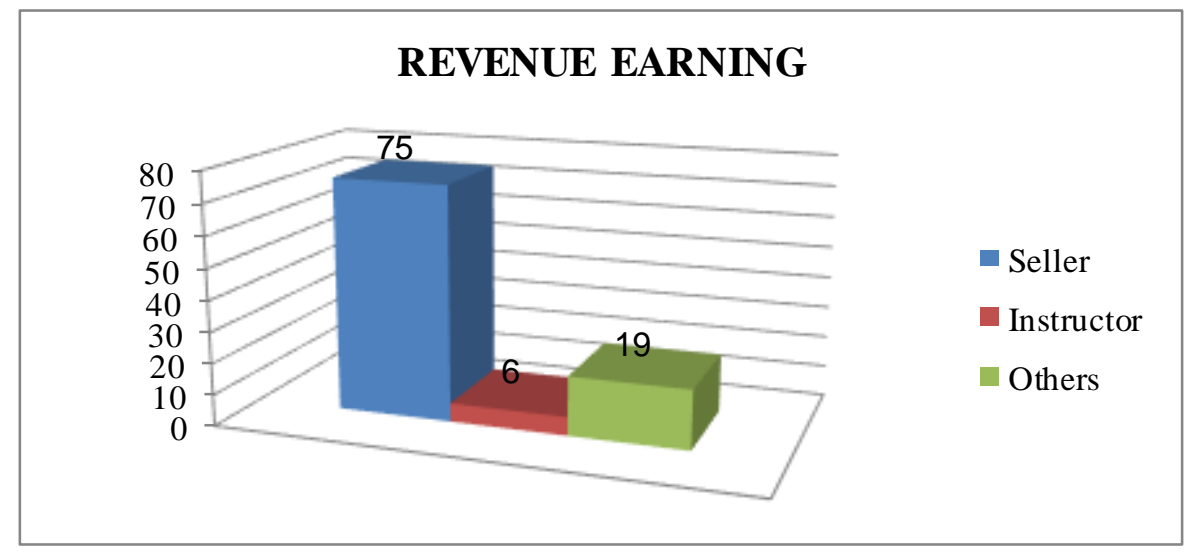

Figure 8. Revenue Earning

Entrepreneurs in Kediri plan to earn $75 \%$ of their income from sales. While the other $25 \%$, operating income is derived from becoming a training instructor and other income such as: income from parking services, income from sales of waste, income from interest services (account receivables). (17)

\section{CONCLUSION}

The research activity on the application of the preparation of business plans for entrepreneurs in Kediri resulted following conclusions: 1) The types of businesses in Kediri city in terms of the results of the preparation of business plans for entrepreneurs in Kediri city include: businesses in the field of culinary, beverages, accessories, souvenirs, institutional services education, beauty services, batik, weaving, tailoring, Muslim clothing, t-shirt producing; 2) The market segments are customer service orientations for the leading business practitioners of Kediri City are mostly adult and adolescent consumers as well as segments of all groups; 3) The types of business promotions planned by Kediri City entrepreneurs are exhibitions, online media, social media, banner, business cards, brochures and direct selling; 4) Kediri City entrepreneurs plan to build relationships with customers through intensive communication with customers, after-sales service and making membership cards; 5) The advantages/bargaining power of Kediri City business practitioners plan is to give to the most consumers/customers excellent service, affordable prices, quality products; 6) Most of the Kediri City entrepreneurs plan for resource requirements including: capital, labour, raw materials and equipment; 7) As an effort to expand business networks, Kediri City entrepreneurs plan to partner with Government Agencies to obtain business development facilitation. Other key partners are Distributors or agents and various communities; and 8) the leading business practitioners in Kediri city, plan their income from the sale of products in addition to several other sources of income.

Acknowledgement: None

\section{Conflict of Interest: None}

\section{Source of Funding: None}

\section{REFERENCES}

1. Ali, W. S., \& Soegoto, H. S. (2016). Studi Kelayakan dan Business Plan Ali Bakri Cake \& Drinks. Jurnal Ilmiah Magister Manajemen UNIKOM, 2(1), 18-33. https://ojs.unikom.ac.id/index.php/jimm/arti cle/view/204

2. Alma, B. (2007). Kewirausahaan. Alfabeta.

3. Andayani, E., Hariani, L. S., \& Ain, N. (2018). Langkah Awal Memulai Usaha Melalui Business Plan. J - ADIMAS (Jurnal Pengabdian Kepada Masyarakat), 6(2), 8488.

https://jurnal.stkippgritulungagung.ac.id/ind ex.php/jadimas/article/view/887/393

4. Aries Suprapto, H., \& Rusdi, M. (2018). Jurnal Pengabdian Kepada Masyarakat 
Sri Wahyuni Mega Hastuti et.al. Analysis of business plan preparation applications as an effort to achieve business success for entrepreneurs of Kediri.

(Abdimas) IKIP Siliwangi Pelatihan Pembuatan Proposal Rencana Bisnis (Business Plan) Bagi Siswa Madrasah Tsanawiyah Nurul Hikmah Dan Smp AlIhsan Guna Meningkatkan Kemampuan Berwirausaha. Abdimas Siliwangi, 01(02), $81-88$.

https://journal.ikipsiliwangi.ac.id/index.php/ abdimas-siliwangi/article/view/905/197

5. Farida, I., Aryanto, A., Sunandar, S., Hetika, H., \& Krisdiyawati, K. (2019). IbM Pelatihan Business Plan Pada Umkm Kota Tegal. Jurnal Pengabdian Masyarakat Progresif Humanis Brainstorming, 2(2), 6468.

https://doi.org/10.30591/japhb.v2i2.1384

6. Hisrich, D. R., \& Peter, M. P. (2008). Enterpreneurship. McGraw Hill.

7. Kristianto, D. (2012). Menyusun Business Plan Dalam Rangka Pengembangan Usaha Djoko Kristianto Fakultas Ekonomi Universitas Slamet Riyadi Surakarta. Jurnal Ekonomi Dan Kewirausahaan, 12(1), 5866.

http://ejurnal.unisri.ac.id/index.php/Ekonom i/article/view/341/301\#

8. Mudjahidin, M. (2005). Perencanaan Bisnis; Organisasi, Lingkungan Bisnis, Manajemen, Dan Sumber Daya Manusia. JUTI: Jurnal
Ilmiah Teknologi Informasi, 4(2), 141. https://doi.org/10.12962/j24068535.v4i2.a2 58

9. Muhammad Hasyim, S. A. (2014). Pelatihan Business Plan Pengembangan Tomat Di Dusun. Jurnal Inovasi Dan Kewirausahaan, 3(2), 90-95. https://journal.uii.ac.id/ajie/article/view/781 $2 / 6792$

10. Purnamasari, I., Hayati, M. N., \& Statistika, P. S. (2018). Analisis Deskriptif Pada Faktor-Faktor Yang. Statistika, 6(2), 114118.

https://jurnal.unimus.ac.id/index.php/statisti k/article/view/4315/3994

11. Supriyanto. (2009). Business Plan Sebagai Langkah Awal Memulai Usaha. Ekonomi Dan Pendidikan, 6(1). https://doi.org/https://doi.org/10.21831/jep.v $6 \mathrm{i} 1.590$

How to cite this article: Hastuti SWM, Surindra B. Analysis of business plan preparation applications as an effort to achieve business success for entrepreneurs of Kediri. International Journal of Research and Review. 2021; 8(7): 117-125. DOI: https://doi.org/10. 52403/ijrr.20210716 